\title{
RISE AND FALL OF CIVILIZATION: CAUSES FROM THE PERSPECTIVE OF THE QUR'AN
}

\author{
Muhammad Mumtaz $\mathrm{Ali}^{1}$, Sayyed Mohamed Muhsin ${ }^{2 *}$ \\ ${ }^{1}$ Professor, Department of Usuluddin and Comparative Religion, Kulliyyah of Islamic Revealed Knowledge and Human \\ Sciences, International Islamic University \\ ${ }^{2}$ PhD Researcher, Kulliyyah of Islamic Revealed Knowledge and Human Sciences, International Islamic University Malaysia
}

*Corresponding author: sayedmuhsinvt@gmail.com

Article history

Received:14/09/2015

Received in revised form:14/09/2015

Accepted: 18/10/2015

\begin{abstract}
The Qur'an contains voluminous portrayals about past civilizations with an imperative exploration to their causes of their rise and fall. The Qur'anic methodologies to survey the realities and events are grounded on ethical, empirical, spiritual, moral, universal and people-oriented appearances. Thus, Qur'an's analysis of past nations differs from the modern Western studies on features of earlier civilizations. From the Qur'anic perspective, the acceptance of True, Authentic and Universal Knowledge [revelation] is considered as the foundational factor for the realization of civilizational growth. Qur'an identifies and proves that human beings are the instrumental and decisive actors in the building of civilization or its destruction. The statements of the Qur'an underscore that whenever people established unethical attitude and denied spirituality in their life and committed immoral acts, they and their civilizations tasted severe declination. This paper emphasizes that dissemination of "justice, unity and service for good" are three important moral concepts that have been mentioned in the Qur'an as integral to rise and fall of civilization.
\end{abstract}

Keywords: The Qur'an, civilization, 'true, authentic and universal knowledge', rise and fall 


\subsection{INTRODUCTION}

The Qur'an presents the stories of several past nations and their civilizations. The emergence, interactions and decline of civilizations have been a frequent area of assessment by historians, sociologists and anthropologists. As a result, a huge collection of literature is available which has dedicated itself to the study of rise and fall of civilizations (Durkheim \& Mauses 1971; Toynbee 1948; Kroeber, 1973; Quiqley, 1961; Rushton, 1959; William, 1963; Wallerstein, 1992). We do not find a systematic study based on the reflections of the Qur'an with regard to the causes and consequences of the growth and collapse of civilization (M. Umer, 2008). It is also noteworthy that wherever, the Qur'an describes the story of past civilizations, it is followed by the explanations of the life stories of the past nations, with special reference to their responses to the True, Authentic and Universal Knowledge and Worldview about the truth and reality of this world.

The debate on the rise and fall of civilization has stirred up more discussion for the last many decades, which enriched much responses and comments regardless of countries and continents. The history of civilizations stretches, through generations from ancient Sumerian, Egyptian to Classical and Mesoamerican through Christian and Islamic civilizations and successive appearances of Sinic and Hindu civilizations (Huntington, 1996). Civilization and culture both refer to the overall way of life of a people, and a civilization is a culture writ large (Huntington, 1996). According to the modern Western scholarship, culture and civilization involve the values, norms, institutions, and modes of thinking to which successive generations in a given society have attached primary importance (Bozeman, 1975).

Civilization is defined by many intellectuals, mainly in the modern Western perspective, through different ways while almost all merge at some common points. A civilization is defined as "a space, a cultural area" or "a collection of cultural characteristics and phenomena" (Braudel, 1980), or "a particular concatenation of worldview, customs, structures, and culture (both material culture and high culture) which forms some kind of historical whole and which coexists (if not always simultaneously) with other varieties of this phenomenon" (Wallenstein, 1992). Some scholars describe civilization as "a particular original process of cultural creativity, which is the work of a particular people" (Dawson, 1956) or it is "a kind of moral milieu encompassing a certain number of nations, each national cultural being only a particular form of the whole" (Durkheim \& Mauses, 1971).

It is also claimed that the major civilizations of world are Sinic (a single distinct Chinese civilization which emerged in 1500 B.C.); Persian Civilization (Achaemenid Persian Empire existed in 550-330 B.C.); Japanese (civilization of Japan which emerged in the period of A.D. 100 and 400), Hindu civilization (existed in the subcontinent since at least 1500 B.C.), Islamic (Originated from Arabian Peninsula in seventh century A.D.), Orthodox civilization (centred in Russia), Western civilization (established in Europe, North America and Latin America emerged in A.D. 700 or 800), and so on (Huntington, 1996).

\subsection{THE QUR'ANIC YARDSTICK FOR MEASUREMENT OF CIVILIZATION}

In order to attain an ideal civilization, the Qur'an provides an applicable and authentic methodology. It stresses as its methodological principle for the development of civilization the application of True, Authentic and Universal Knowledge and does not leave any room for intellectual speculation and conjecture. The Qur'an, as a decisive factor and reminder for the civilizational development, presents repeatedly the accounts of historical records of past nations, civilizations and of their rise and fall. It prompts people to reflect on the responses of previous generations towards the True, Authentic and Universal Knowledge and Worldview. The Qur'an emphasizes this on the basis of ethical and empirical approach, spiritual and moral understanding and universal and people - oriented perspective. According to the Qur'anic point of view, the abovementioned features are measured as the fundamental axioms of a scientific analysis. The nations, societies, people of particular regions mentioned in the Qur'an signify the essential connotations of different civilizations, in the light of which contemporary humanity can choose their future and determine the subsequent results in accordance with their current worldviews and activities. 
The Five Different Levels of Categories of Factors which are Necessary for Rise of a Civilization as emphasized by the Qur'an

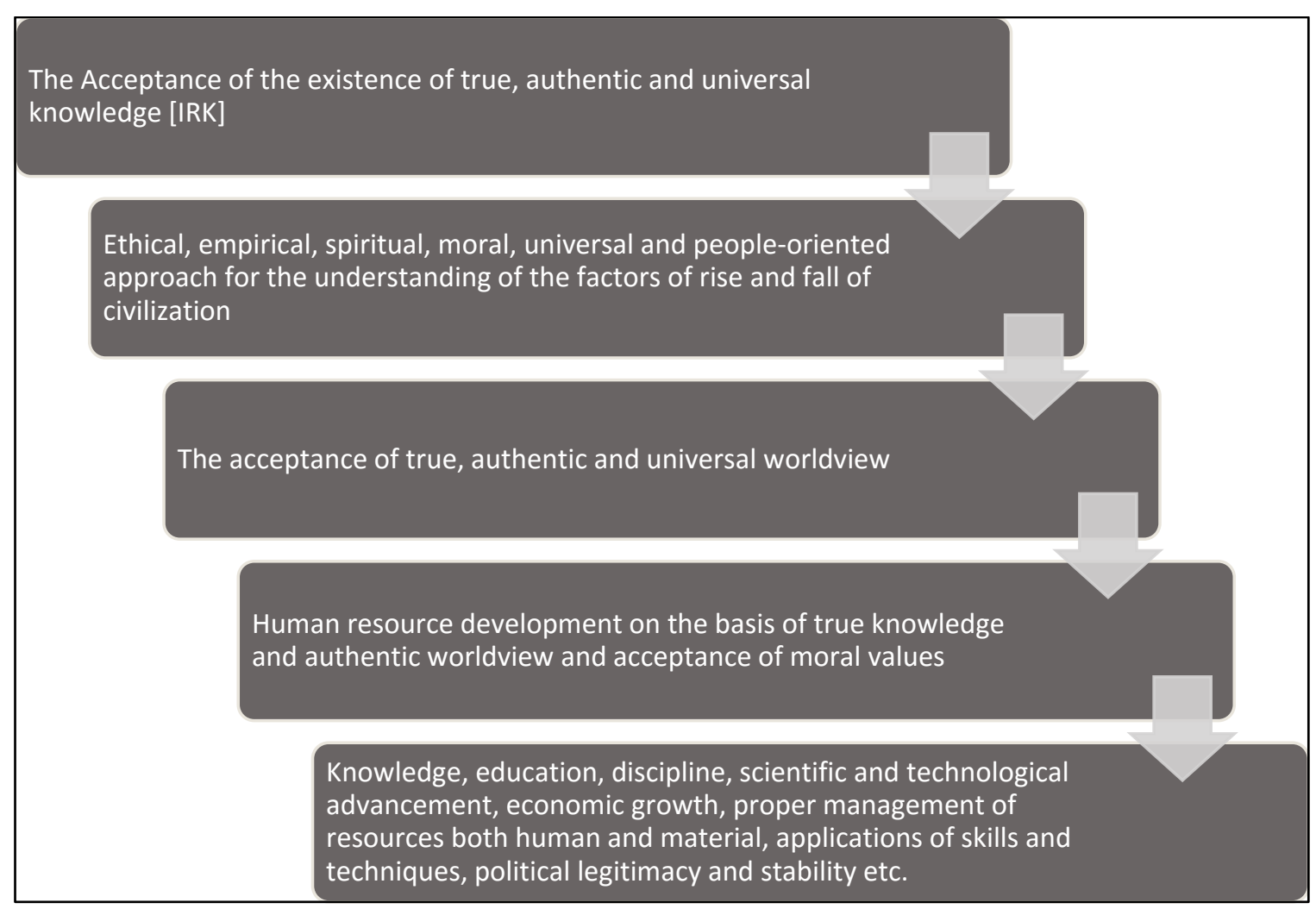

The thought developed by human faculties throughout history had neglected the abovementioned first four categories or factors and emphasized the fifth one as decisive factor. The human thought free from True, Authentic and Universal Knowledge used to put emphasis on the so-called facts and realities in terms of material achievements and development of skills. Based on the parameters of ethics, empirical evidence, spirituality, morality, universality and people-oriented concerns, the Qur'an suggests the true path of civilizational development. It argues the realization of the existence of True, Authentic, and Universal Knowledge, comprehension of spirituality [creation and purposefulness of all existence], acceptance of moral values, and True Worldview constitute the first and fundamental category of factors. The True and Realistic Worldview, against false worldviews, becomes integral aspect of the process of civilizational development. The Qur'an indicates to this reality:

Then there are some who say, "We believe in Allah and the Last Day", whereas they do not believe at all. They thus try to deceive Allah and the Believers, but they succeed in deceiving none except themselves and they realize it not. In their hearts is a disease which Allah has increased all the more and a painful doom is in store for them for the lie they utter. Whenever it is said to them, "Spread not disorder on the earth", their reply is, "We only seek to put things aright". Beware! they do spread disorder but they realize it not. And when it is said to them, "Believe sincerely as the other people have believed", they reply, "Should we believe as fools have believed?" Beware! they themselves are the fools, but they know it not. (al-Baqarah: 8-12)

The acceptance and application of True, Authentic and Universal Knowledge and Worldview is considered the most fundamental factors towards the development of civilization. In the fourth category, the Qur'an includes human resources, who are ethically, spiritually and morally trained based on True, 
Authentic and Universal Knowledge. The Qur'an refers to them with different terms and some of them are mu'minun (al-Baqara: 221), muhsinun (Al 'Imran: 134), muttaqun (al-Baqara: 241), Salihun (al-A'raf 77) and so on. Moreover, the Qur'an categorically declares that those who do not depend on True, Authentic and Universal Knowledge and deny ultimate Truth and Reality demonstrate unethical, unspiritual and immoral attitude and destroy civilization as they create disorder. According to the Qur'an, these people fail to develop civilization because they create chaos and crisis in life and societies. They are, therefore, called by different terms in the Qur'an like mujrimun (Maryam: 86), Zalimun (al-Baqarah: 35), munafiqun (alFath: 6), kafirun (al-Kafirun:1) and mufsidun and so on. The fifth category covers the factors such as true knowledge, proper education, discipline, scientific and technological advancement, economic growth, proper management of resources both human and material, application of skills and techniques, political legitimacy, management etc. The modern Western perspective of civilization is, therefore, different from the Qur'anic perspective. The modern Western perspective bases its intellectual discourse more on historical happenings and intellectual speculation. It is evident, as asserted by some scholars, that the classical European and the modern Western perception of history of civilizations differ from that held by most Muslim scholars. It is said that a new civilization arises when priority is given

...to the ability of humans in dealing with material factors such as economy, politics, technology and other material elements of life in a given civilization. These elements, if they are well practiced, are considered as being the sustenance of civilization, and if they are mismanaged and become weakened, are considered as being the cause of decline and may lead to the complete fall of civilization. These elements remain at a higher level in any civilizational process than the spiritual, ethical and moral elements. This ancient perception has had a great influence on Western interpreters of modern history on their image of civilizations (Suleman, 2006). [emphasis is added]

As a consequent, in the modern Western discourse on civilization the fundamental factors such as ethical, empirical, spiritual, moral, universal and people-oriented have been largely ignored, and sometimes totally denied. This happened due to unethical emphasis and application of the use of conjecture, speculation, imagination, desires, fancies, and imaginations in the process of thinking and understanding. The modern Western deterministic approach to the rise and fall of civilizations accept the hand of certain factors that are beyond the human capacity and control (Toynbee, 1948). Toynbee (1948) elaborated:

We have now disposed of three deterministic explanation of the breakdown of civilizations: the theory that they are due to the running down of the 'clockwork' of the Universe or to the senescence of the Earth; the theory that a civilization, like a living organism, has a life-span determined by the biological laws of its nature; and the theory that the breakdowns are due to a deterioration in the quality of the individuals participating in a civilization, as a result of their pedigrees' accumulating too long a tale of 'civilized' ancestors.

Toynbee discussed only the phenomena that have appeared as a result, not touched the area of causes and reasons for this decline of civilization (Boayo, 2006). Toynbee identified following notions that is 1] failure of creative power in the minority of the ruling class, 2) reluctance of majority to follow the ruling party and finally 3 ) consequent loss of social unity in the society (Boayo, 2006).

\subsection{RATIONALITY OF QUR'ANIC INSIGHT ON CIVILIZATION}

The understanding of the link between True, Authentic and Universal Knowledge, and the True Worldview and the application of ethical, empirical, spiritual, moral, universal and people-oriented method is of utmost important. These are main and indispensable factors for the rise of a civilization. From the Quranic perspective, the building of a civilization and its fall is intimately connected with the acceptance or denial of people towards the True, Authentic and Universal Knowledge and True Worldview. One needs to understand that the only way out left for humanity is to accept [based on a thorough ethical examination and empirical evidence] that the Qur'an is the only source of True, Authentic and Universal Knowledge of the physical and metaphysical world.

The speculative foundation of metaphysics, epistemology, methodology, knowledge and education, which is fundamentally a false foundation and full of harmful consequences for humankind, which also 
goes against Truth and Reality of this world as proclaimed by the Qur'an, has caused decline of the civilization in the contemporary world. This state of civilization has to be changed (Muhammad Mumtaz Ali, 2014). The foundation of modern knowledge and education, which is unethically based on speculation and conjecture, needs to be replaced by a new foundation of True, Authentic and Universal Knowledge about man, society, physical and metaphysical world. It realistically conforms to Truth and Reality of the world and yield best practical results. We may further argue that our understanding of the existence of true, authentic and universal knowledge is not based on our philosophical search. It is not the result of the various religious traditions; or the Greek and Hellenistic philosophical tradition; or modern Western philosophical or scientific tradition; or the Occidental and Oriental mystical traditions. Rather, we acquire this understanding based on a through reading and examination of the Qur'an.

Philosophers of modernity declared man is free from Allah (SWT.) and His Guidance. They pronounced that man is capable to understand each thing of this world by himself. Whereas, we see in the Qur'an that Allah (SWT.) has declared repeatedly in the Qur' an that man is not at all capable to understand the truth and Reality of both metaphysical and physical worlds. Hence, He has sent for the guidance of mankind hundreds of thousands of Prophets [p.b.u.t.] throughout history but man out of his ignorance and arrogance deny to understand this fact of life and developed false understandings and gave them names of knowledge, science, philosophy, metaphysics and ethics.

If man can understand independently the true nature of metaphysical realities then there was no need of Prophets [p.b.u.t.] and Guidance. Moreover, the Prophets like Adam; Idris (Enoch); Nuh (Noah); Hud (Heber); Salih (Methusaleh); Lut (Lot); Ibrahim (Abraham); Ismail (Ishmael); Ishaq (Isaac); Yaqub (Jacob); Yusuf (Joseph); Shu'aib (Jethro); Ayyub (Job); Dhulkifl (Ezekiel); Musa (Moses); Harun (Aaron); Dawud (David); Sulayman (Solomon); Ilias (Elias); Alyasa (Elisha); Yunus (Jonah); Zakariya (Zachariah); Yahya (John the Baptist); Isa (Jesus), and Muhammad, peace and blessings upon all of them, would become falsifiers who claimed that they have come to disseminate a special kind of knowledge [True, Authentic and Universal Knowledge] about the physical and metaphysical realities of this world (Muhammad Mumtaz Ali, 2014).

Here one can pose some fundamental questions, which require answers from the proponents of the modern Western civilization, which has been built upon speculation and conjecture. Can we ignore Allah (SWT.) and march on to the path of physical and metaphysical understanding and develop the structure of philosophical thought? If we ignore Allah (SWT.) and His Book, is this attitude be an ethical [rational] attitude? Has any other philosopher, thinker, scholar or author, other than Allah [SWT], made claim about himself that he knows everything and his book encompasses everything? Who has the unlimited Knowledge, wisdom and Power over each and every thing of this world, philosophers or Allah (SWT)?, So turning away from Allah [SWT] and His book the Qur'an, would be ethically irrational and will lead to the wiping out of contemporary world and to the decline of a civilization (Muhammad Mumtaz Ali, 2014).

\subsection{THE CENTRAL ROLE OF HUMAN BEINGS TOWARDS THE DEVELOPMENT OF CIVILIZATION}

Based on the discussion of the Qur'an concerning the past civilizations, one can note two points: 1) man is the central figure of all discussions and reflections of the Qur'an and 2) human beings are the instrumental and decisive actors in the building of civilization or its destruction. The following statements beam light on the perspective of the Qur'an with regard to the unethical attitude of human beings and their sublime objectives among other creatures of the universe.

1. It is a favour that We have honoured the sons of Adam and blessed them with conveyances on land and sea and provided them with good and pure things and exalted them above many of Our other creatures. (al-Isra',71)

2. Just recall the time when your Lord said to the angels, "I am going to appoint a vicegerent on the Earth" (al-Baqarah, 30). 
3. (We said :) "O David, We have made you vicegerent in the earth, so rule among the people with justice and do not follow your lust, for it will lead you astray from Allah's Way." For those who go astray from Allah's Way, there is a severe punishment because they forgot the Day of Reckoning." (Saad, 26).

Having mentioned the central role of human beings on the earth and their preference to other creatures, it would be interesting to note that the Qur'an puts human beings accountable for the destinies happening to the societies, people, universe, and empires, which are the usual connotations of the civilizations. The Qur'an verifies:

1. The fact is that Allah does not change a people's lot unless they themselves change their own characteristics: and when Allah decides to bring about retribution to a people, none can ward it off, nor can they find any defender or helper against Allah. (al-Ra'd, 11).

2. This happened in accordance with Allah's way that He does not withdraw the favour He bestows on any people unless they themselves change their ways. Allah hears everything and knows everything. (al-Anfal, 53).

3. Mischief has appeared in the land and the sea on account of men's own doings that $\mathrm{He}$ may make them taste same of their (evil) works: maybe they mend their ways. (al-Rum, 41)

The Qur'an confirms that the yardstick of rise and fall of civilization forms through the responses of human beings to the Truth and Reality of the world. The examination of existing concepts and realities of world grounded on the principles of ethics, empirical evidence, spirituality, morality, and universality, reveal the fact that current conditions of life have been initiated and completed by the rejection of Truth and embrace of conjecture.

\subsection{THE QUR'ANIC PERSPECTIVE ON CIVILIZATIONAL DEVELOPMENT}

The Qur'an sheds light to the fact that people's response to Truth and Reality is the root cause of rise and fall of civilization. The Qur'an has emphasized the role of the principles of ethics, empirical evidence, spirituality, morality and universality in the rise of civilization. The Qur'an points out:

1. Had the people of the habitations believed and adopted the way of piety, We would have opened the doors of blessings from the heavens and the earth. (al-Qur'an: al-A'raf, 96).

2. Had they observed the Torah and the Gospel and the other Books which had been sent down to them by their Lord, abundance would have been given to them from above and from beneath. Though there are some among them who are righteous. (al-Qur'an: $a l-M a$ 'idah, 66).

3. Whosoever does righteous deeds, whether male or female, provided he is a Believer, We will surely grant him live a pure life in this world. And We will reward such people (in the Hereafter) according to their best deeds. (al-Qur'an: al-Nahl, 97)

4. Believe it that We do help Our Messengers and the Believers in the life of this world, and so shall We help them on that Day also when the witnesses shall stand up, and the excuses of the wrongdoers shall not avail them anything. (al-Qur'an: al-Ghafir, 51)

The guidance, assistance and blessings are guaranteed by Almighty Allah [SWT] Himself for the people who maintain piety and perform the righteous deeds, apply principles of ethics in their lives. Achieving the high level of ethical, empirical, spiritual and moral excellence in life, individually and collectively as a whole along with high level of political, economic, scientific, technological advancement is measured as the core elements of the rise of civilization. It should be underscored that the material and spiritual aspects of life are not separated but they are integral as well as unified. 


\title{
6.0 THE QUR'ANIC STANDPOINT ON THE FALL OF CIVILIZATION
}

Elaborating the real causes of fall of civilizations, the Qur'an contains several statements based on the experiences of the past civilizations. One of the causes that are mentioned in the Qur'an is related to the ungrateful attitude of past nations. Instead of acknowledging the blessings of Allah [SWT] and accepting Him as their Lord they either neglected or rejected Him. This attitude of people is understood as the undesirable approach of people towards Truth and Reality. The whole humanity is expected to take serious note of these statements of the Qur'an. Narrating what happened to the nation of Saba', and others the Qur'an explains:

But they turned away (from Allah), and We sent against them the Flood (released) from the dams, and We converted their two garden (rows) into "gardens" producing bitter fruit, and tamarisks, and some few (stunted) Lote-trees. That was the requital We gave them because they ungratefully rejected faith: and never do We give (such) requital except to such as are ungrateful rejecters. (Qur'an: Saba': 15-17)

Another example of a township is provided in the Qur'an, the inhabitants of which developed unethical [irrational] approach towards Truth and Reality of this world and True, Authentic and Universal Knowledge, their destiny culminated in the eternal loss and fall of civilization.

\begin{abstract}
Allah cites the instance of a habitation: it was enjoying a life of peace and security and was receiving its provisions in abundance from every quarter. But when it began to show ingratitude towards the favours of Allah, He made its inhabitants taste the consequences of their doings, and inflicted misfortunes of hunger and fear on them. A Messenger came to them from among themselves but they treated him as an impostor. At last a torment overtook them while they had become guilty of iniquity. (Qur'an: Nahl, 112).
\end{abstract}

What occurred to the people of Prophet Nuh refers to same approach of blind rejection of True, authentic and universal knowledge and arrogant refutation of the acceptance of Truth and Reality. The Qur'an describes:

Nuh said, "O my Lord, they have disobeyed me and followed those (chiefs) whose wealth and children have increased them only in loss. They have devised a mighty plot. They said, "Do not at all abandon your gods, and do not abandon Wadd nor Suwa, nor Yaghuth and Ya'uq and Nasr." They have led many people astray, and so (O Lord), increase not the wrongdoers in anything but deviation." (Qur'an: Nuh, 21-24).

Ibn 'Abbas, 'Ikrima, Zahhak have commented on this ayah that: "Subsequent upon the death of those righteous men, Satan motivated the innocent people to create the statues in the places where they used to sit. They erected the statutes but did not offer any activities similar to the worship. After their time, the succeeding generation went beyond the respect to the level of worship. Ibn Jarir narrated: "There were righteous people who lived in the period between Adam and Nuh and who had followers who held them as models. After their death, their friends who used to emulate them said: 'If we make statues of them, it will be more pleasing to us in our worship and will remind us of them.' So, they built statues of them, and, after they had died and others came after them, Iblis crept into their minds saying: 'Your forefathers used to worship them, and through that worship they got rain.' So they worshipped them."

The same was the case with the people of Noah when they charged the Messenger with imposture.We drowned them and made them a sign of warning for entire mankind, and We have prepared a painful chastisement for the unjust. (Qur'an: al-Furqan, 37)

There are so many other statements of the Qur'an, which denote to the fall of many civilizations from which one can draw certain common conclusions and see the reasons, which led to the destruction of civilizations. See the following statements of the Qur'an regarding the fall of civilization.

1. But how many (countless) generations before them have We destroyed? Can you find a single one of them (now) or hear (so much as) a whisper of them? (al-Qur'an: Maryam: 98). 
2. And the (disbelievers) must indeed have passed by the town on which was rained a shower of evil: did they not then see it (with their own eyes)? But they fear not the Resurrection. (alQur'an: al-Furqan: 40)

3. See they not how many of those before them We did destroy? Generations We had established on the earth, in strength such as We have not given to you, for whom We poured out rain from the skies in abundance, and gave (fertile) streams flowing beneath their (feet): yet for their wrong actions We destroyed them, and raised in their wake fresh generations (to succeed them). (al-Qur'an: al-An'am: 6)

4. But how many generations before them did We destroy (for their wrong actions), stronger in power than they? Then did they wander through the land: was there any place of escape (for them)? Verily in this is a message for any that has a heart and understanding or who gives ear and earnestly witnesses (the truth). (al-Qur'an: Qaf: 36-37)

5. Has not the story reached you, (O people!), of those who (went) before you? Of the people of Nuh, and 'Aad and Thamud? And of those who (came) after them? None knows them but Allah. To them came messengers with clear (signs); but they put their hands up to their mouths, and said: "We deny (the mission) on which you have been sent, and we are really in suspicious (disquieting) doubt as to that to which you invite us." (al-Qur'an: Ibrahim: 9).

6. The (mighty) blast overtook the wrongdoers, and they lay prostrate in their homes before the morning, as if they had never dwelt or flourished there. Ah! Behold! For Thamud rejected their Lord and Cherisher! Ah! Behold! Removed (from sight) were Thamud! (al-Qur'an: Hud: 6768)

7. Does it not teach them a lesson, how many generations We destroyed before them, in whose dwellings they (now) go to and fro? Verily in that are Signs: Do they not then listen? (al-alSajdah: 26).

\subsection{SUMMARY OF THE CAUSES OF FALL OF PAST CIVILIZATIONS}

The statements of the Qur'an underscore that whenever people established unethical attitude, denied spirituality in their life, and committed immoral acts, they and their civilizations declined. The other important reasons of decline of past civilizations as mentioned in the Qur'an are as follows:

1. Conscious transgression of the boundaries of ethics and spirituality.

2. Becoming immoral or changing the morals.

3. Persistence on the application of conjecture and speculation

4. Consideration of Prophets as liars and mere ordinary men.

5. Adopting the attitude of ignorance.

6. Disregard to the threat of the punishment of Allah [SWT]

7. Exceeding arrogance.

In nutshell, the ungrateful and irrational nations have always been tested by the destruction and ultimate fall of civilization. Belying of Prophets, blessing and peace upon all of them, and exceeding immorality become precisely reasons for the failure of major societies since it is essentially the rejection of Truth and Reality.

There are some other principles which always have been kept before people those demonstrate the causes of decline or destruction of all past civilization. They are:

1. Prior warning- "And your Lord would never destroy habitations until He had sent in their central place a Messenger, who recited to them Our Revelations; and We would not destroy Habitations until their dwellers had become wicked." (al-Qur'an, al-Qasas: 59)

2. Giving a time for repenting- "Your Lord is very Forgiving and very Merciful: Had He willed to seize them for their evil deeds, He would have sent immediately a scourge on them but $\mathrm{He}$ has appointed a time for its fulfilment, and they will find no way out to escape from it. These habitations which were stricken with the scourge are before you when they committed iniquity 
We annihilated them, and We had appointed a term for their annihilation”. (al-Qur'an, al-Kahf: 58-59)

3. Trial punishment before real punishment-"Mischief has appeared in the land and the sea on account of men's own doings that He may make them taste same of their (evil) works: maybe they mend their ways. The punishment is not meted out for all sins in this world; otherwise all people would have been destroyed." (al-Qur'an, Rum: 41)

There are three more important moral concepts, which have been mentioned in the Qur'an as integral to rise and fall of civilization (Suleiman, 2006).

\section{Justice and Injustice}

A. Allah enjoins you to give the trusts into the care of those persons who are worthy of trust and to judge with justice when you judge between the people. Excellent is the counsel that Allah gives you, for Allah hears everything and sees everything. (al-Qur'an: al-Nisa', 58)

B. O Believers, be you the standard-bearers of justice and witnesses for the sake of Allah, even though your justice and your evidence might be harmful to yourselves, or to your parents, or to your relatives. It does not matter whether the party concerned is rich or poor: Allah is their greater wellwisher than you; therefore, do not follow your own desire lest you should deviate from doing justice. If you distort your evidence or refrain from the truth, know it well that Allah is fully aware of what you do. (al-Qur'an: al-Nisa', 135).

C. Give full measure and do not give people less than what is due to them; weigh with even balance and do not cheat people of their goods; and do not spread evil in the land, and fear Him Who has created you and those who have gone before you." (al-Qur'an: al-Shura', 181-183).

\section{Unity and Disunity}

A. Hold fast together to the cable of Allah and be not divided. (al-Qur'an: Al- 'Imran, 103).

B. And do not be like those, who became divided into sects and got involved in differences of opinion even after receiving clear teachings (al-Qur'an: Al- 'Imran, 105).

\section{Enjoining the Good and Forbidding the Evil}

A. There should always be among you some people who invite to what is good and enjoin what is right and forbid what is wrong: They alone will attain true success. (al-Qur'an: Al- 'Imran, 104).

B. they would not forbid one another to do the wrong deeds they committed (al-Qur'an: al-Ma 'idah, 79).

\subsection{CONCLUSION}

The investigation into the root causes of rise and fall of nations and civilizations offers some different perspectives sheds light to certain significant outcomes. The Qur'an emphasizes dynamics of rise of the civilization on the basis of ethical, empirical, spiritual and people-oriented characteristics. It gives fundamental role to the True, Authentic and Universal Knowledge and the undercurrents of decline based on the denial of Absolute Truths. Turning away from True, Authentic and Universal Knowledge and True Worldview tantamount to the decline of civilization. While throughout history, the source of True, Authentic and Universal Knowledge has been the revealed books of Almighty Allah [SWT] in the respective times and the words and deeds of Prophets, peace and blessings upon all of them, whom Almighty Allah [SWT] appointed for particular societies to guide them. Rejection of True One God and the Day of Resurrection and conscious transgression of the boundaries of ethics, spirituality and morality; consistent insistent in doing sins and wrongs are the significant reasons of fall of civilizations. 


\section{References}

Al-Quran

Boayo, S. M. H. (2006). The Role of Morality AkhlÉq in the Rise and Decline of Civilizations: Aspects of the Muslim Interpretation of Roman Civilization's Decline. Unpublished PhD thesis. Kuala Lumpur: International Islamic University Library.

Bozeman, (1975). Civilizations under stress. Virginia Quarterly Review, 51, pp1

Bozman, A. B. (1975). Civilizations under stress, Virginia Quarterly Review, 51.

Braudal, F. (1980). On History. Chicago: University of Chicago Press. pp177, 202.

Braudel, F. (1980). On History. Chicago: University of Chicago Press.

Dawson, C. (1956). Dynamic of World History, John J. Malloy (Ed.),New York: Sheed and Ward.

Durkheim, E. and Mauses, M. (1971).Note on the notion of civilization. Social Research, 38, pp 808-813.

Huntington, S. P. (1996). The Clash of Civilizations and the Remaking of World Order. New York: Simon $\&$ Schuster.

Jean-Francois, L. (1984). The Postmodern Condition: A report on knowledge, vol.10. USA: University of Minnesota.

Kroeber, A. L. (1944) Configurations of Culture Growth, Berkeley: University of California Press.

Kroeber, A. L. (1944). Configurations of Culture Growth. Berkeley: University of California Press.

Kroeber, A. L. (1973). Style and Civilizations. Westport: CT: Greenwood Press.

M. Umer, C. (2008). Muslim Civilization: The Causes of Decline and the Need for Reform. The Islamic Foundation, Leicestershire, United Kindom.

Muhammad Mumtaz, A. (2014). Issues in Islamization of Human Knowledge: Civilization Building Discourse of Contemporary Muslim Thinkers. Kuala Lumpur, IIUM Press.

Quiqley, C. (1961). The evolution of Civilizations: An Introduction to Historical Analysis. NewYork: Macmillan.

Rushton, C. (1959). The Origin of Civilized Societies. Princeton: Princeton University Press.

Toyenbee. A., (1934-1961). A Study of History. London: Oxford University Press, 12 vols.

Toyenbee. A., (1948). "Civilization on trial and the World and West" in The Argument of a Study of History, summarized by D.C. Somervell, Oxford: Oxford University Press Inc.

Wallerstein, I., (1992). Geopolitics and Geoculture: Essays on Changing World System. Cambridge: Cambridge University Press.

William H. M. (1963). The Rise of the West: A History of the Human Community. Chicago: University of Chicago Press. 